\title{
Novel genomic variants associated with polysplenia, situs inversus totalis, atrial septal defect and double outlet right ventricle in Saudi patient
}

\author{
Yousef Mohammedrabaa Hawsawi ${ }^{1}$, Turki Mohammed Sobahy Sobahy ${ }^{1}$, Samar Zailaie ${ }^{1}$, \\ Mohammed Baghdadi ${ }^{1}$, Donya Bahussain ${ }^{1}$, Othman Al-Zahrani ${ }^{2}$, Chellasamy \\ Panneerselvam ${ }^{2}$, Edward Cupler ${ }^{1}$, and Amjad Al-Kouatli ${ }^{1}$ \\ ${ }^{1}$ King Faisal Specialist Hospital and Research Centre - Jeddah \\ ${ }^{2}$ University of Tabouk Faculty of Science
}

April 27, 2020

\begin{abstract}
In this case study, we reported a case of 8-year-old Saudi patient diagnosed with polysplenia, situs inversus totalis and double outlet right ventricle. We identified five novel missense mutation in three genes GATA4, NIPBL and APC as causative mutations and could be used for early detecting of polysplenia syndrome.
\end{abstract}

Hosted file Polysplenis case revised 14-4-2020[2602] 24-04-2020.pdf available at https://authorea.com/users/315337/articles/4 novel-genomic-variants-associated-with-polysplenia-situs-inversus-totalis-atrial-septal-defect-and-double-outletright-ventricle-in-saudi-patient

Hosted file Figures for the Polysplenis case 10-4-2020.docx available at https://authorea.com/users/315337/articles/445720novel-genomic-variants-associated-with-polysplenia-situs-inversus-totalis-atrial-septal-defect-and-double-outletright-ventricle-in-saudi-patient 